\title{
Miedos y suspicacias: interdicción y cultura escrita en la época de la Contrarreforma
}

\author{
Fears and suspicions: interdiction and written culture at the time of Counter- \\ Reformation
}

\author{
Medos e suspeitas: interdição e cultura escrita durante a Contrarreforma
}

\author{
Carlos Alberto González Sánchez \\ Universidad de Sevilla \\ calberto@us.es
}

\begin{abstract}
Resumen: El control ideológico y la censura a lo largo de la historia han generado un sinfín de controversias en torno al libro y la lectura, con fin de distinguir lo bueno de lo malo; es decir, los textos que se debían leer, o simplemente poseer, y los que había que erradicar. La aparición de la imprenta, debido a su potencial multplicador y su capacidad de difusión, hizo que los distintos poderes, civiles y religiosos, radicalizaran la vigilancia de la producción del escrito y su circulación, porque veían peligrar los fundamentos de la ortodoxia cultural y, en definitiva, del sistema establecido. Por ello en este artículo se examinan distintas estrategias de interdicción que dieron lugar a numerosas prohibiciones de libros y autores, sobre todo en el Mundo Atlántico de los siglos XVI y XVII.
\end{abstract}

Palabras claves: Censura; libro; lectura; mundo Atlántico; Contrarreforma.

Resumo: O controle ideológico e a censura, ao longo da história, tem possibilitado inúmeras controvérsias em torno do livro e da leitura, com a finalidade de distinguir o bem do mal; quer dizer, os textos que se deviam ler, ou simplesmente possuir e aqueles que deviam ser erradicados. O aparecimento da imprensa, devido a seu potencial multiplicador e a sua capacidade de difusão, fez com que os diversos poderes, civis e religiosos, radicalizassem a vigilância sobre a produção do escrito e sua circulação, uma vez que este vinha ameaçar os fundamentos da ortodoxia cultural e, em definitivo, o sistema estabelecido. Dessa forma, nesse artigo se examinam as distintas estratégias de interdição que deram lugar a numerosas proibições de livros e autores, sobre todo o Mundo Atlântico dos séculos XVI e XVII.

Palavras-chave: Censura; livro; leitura; mundo Atlântico; Contra Reforma.

Abstract: The ideological control and censorship, throughout history, has enabled numerous controversies around the book and reading, in order to to distinguish good from evil; in other words, the texts that should be read, or just owned and those which should be eradicated. Due to its potential multiplier and diffusion capacity, the first printing press provided that both civil and religious powers put tremendous surveillance on the production and circulation of writing, since this had been threatening the foundations of cultural orthodoxy and, ultimately,the established system. Thus, this paper will examine the different strategies of prohibition which gave rise to numerous bans on books and authors on the entire Atlantic World of the sixteenth and seventeenth centuries.

Keywords: Censorship; book; reading; Atlantic World; Counter Reform.

Artigo recebido para publicação em: setembro de 2014

Artigo aprovado para publicação: novembro de 2014 


\section{Introducción}

A lo largo de la historia los discursos y su lectura, en las diversas formas que pueden adoptar, han sido objeto de control y selección, de ordenación y distribución dentro de unos cauces definidos y mediante un sistema normativo concebido con el fin de anular los riesgos, ciertos o previsibles, que los distintos poderes establecidos en cada momento perciben. ${ }^{1}$ En este entramado de dirección ideológica, la actuación de sus artífices y agentes, en aras de acrecentar y preservar el estatus e ideario que representan, no sólo es característica de las sociedades de tiempos remotos; pues de muy diversas maneras todavía persiste e, incluso, en función de los medios disponibles en la actualidad, cuenta con mayores garantías de eficacia y rigor. Eso sí, disimulada en una cultura de masas supuestamente progresista y justificada desde la libertad de elección individual. Hoy día la tutela de la opinión pública se puede detectar en los niveles a los que ha llegado el monopolio de la verdad, las autoridades e ideologías reconocidas, la influencia de los medios de comunicación, los organigramas didácticos y pedagógicos y los mecanismos de marginación del pensamiento que se aparta de una visión de la realidad uniforme y de un orden socio-cultural homogéneo. ${ }^{2}$

¿De dónde derivan, si no, los criterios seguidos en la formación de una biblioteca oficial; a qué responden los gustos lectores predominantes, la edición de un texto y su éxito o fracaso comercial? Sin duda, la calidad "objetiva" de las obras y la fama de los autores pueden estar por encima de cualquier consideración; pero, ¿acaso no predisponen los ánimos de los que participan en el juego las revistas especializadas, los catálogos de prestigio, los críticos renombrados, los profesionales del libro (escritores, editores, libreros, profesores, etc.), los periódicos, la radio, la televisión y los patrones educativos en escena? Todos ellos son factores que tienden a delimitar las pautas de conducta de los que toman las decisiones al respecto y, lo más importante, las del público receptor; este último, como bien expresa Petrucci, siempre ha estado educado y guiado en el uso de una cultura escrita que quiere ser antes que nada vendible $y$, por tanto, de masas. ${ }^{3}$

Volvamos ahora la vista atrás y contemplemos esta compleja empresa de interdicción ideológica en la España de la Contrarreforma, cuando la imprenta comenzaba a poner de manifiesto unos efectos imprevisibles. Corresponde la trama por tanto a una época histórica de despiadada y violenta censura, la misma que fluye, aunque en un siglo posterior, el XVIII, en la novela de García Márquez Del amor y otros demonios, en la que el clérigo protagonista, Cayetano Delaura, recuerda su juvenil ingreso en el seminario, en donde, nada más llegar, el rector le vetó la conclusión de la lectura del libro que encontraron en su baúl y que empleó para hacer más liviano el viaje hasta allí; cuyo título, dado el mal estado de conservación del volumen, desconocía. El impreso confiscado, "descosido, incompleto y sin carátulas, tal como él lo rescató por azar de unos cajones de su padre”, entonces estaba proscrito por ser contrario a la salud del alma y las buenas costumbres.

Veintiséis años después, "en la umbría biblioteca del obispado, cayó en la cuenta de que había leído cuantos libros pasaron por sus manos, autorizados o no, menos aquél. Lo estremeció la sensación de que una vida completa terminaba aquel día. Otra, imprevisible, empezaba”. Gracias al médico Abrenuncio volvió a ver el texto por el que hubiera dado "cualquier cosa por conocer el final". Lo reconoció al primer golpe de

\footnotetext{
${ }^{1}$ Este trabajo se inscribe dentro del Proyecto I+D+I Inquisición, cultura y vida cotidiana en el Mundo Hispánico (siglos XVI-XVIII), Ref. HAR2011-27021, del Ministerio de Economía y Competitividad.

2 Todavía resulta muy sugerente FOUCAULT, Michel, El orden del discurso. Barcelona: Tusquets, 1999. También PETRUCCI, Armando, "Leer por leer: un porvenir para la lectura", en CAVALLO, G. y CHARTIER, R. (dirs)., Historia de la lectura en el mundo occidental. Madrid: Taurus, 1997, pp. 519-550.

${ }^{3}$ PETRUCCI, "Leer por leer...", op. cit.
} 
vista y pudo saber que se trataba de una antigua edición sevillana de Los cuatro libros del Amadís de Gaula. Sí, un libro prohibido dijo Abrenuncio, "como las mejores novelas de estos siglos. Y en lugar de ellas ya no se imprimen sino tratados para hombres doctos. ¿Qué leerían los pobres de hoy si no leyeran a escondidas las novelas de caballería?"4.

\section{Las secuelas de la imprenta}

El potencial intelectual inherente a las novedades técnicas de la imprenta, pronto desencadenó desconfianza y temor en las autoridades civiles y religiosas de la segunda mitad del siglo XV. Aquel logro, al poco de nacer, puso de relieve su utilidad en muy diversos frentes, pero también consecuencias perversas si se prestaba a la propagación de conocimientos nocivos para la comunidad. Por ello comenzó a acrecentar sospechas y a ser vista desde el poder como un mal que, con el fin de limitar y orientar su capacidad multiplicadora, debía ponerse al servicio de fines superiores; sólo así quedarían justificados los beneficios del invento. Sembrar la palabra de Dios y el cuidado de su pureza habrían de ser sus deberes primordiales, una meta que necesariamente no implicaba, aunque algunos lo desearan, la exclusión de objetivos intelectuales diferentes, pero siempre que no perjudicaran a las creencias. Los recelos del cronista Pero Mexía (1497-1551) hacia el arte maguntino, no le impedían afirmar a la vez que "el usar mal algunos de la arte, no le quita a ella su bondad y perfección". ${ }^{5}$

No hubo en la España de los Reyes Católicos (1474-1516) mayor acontecimiento cultural que la llegada, en 1472, de la tipografía, coincidiendo con una etapa de esplendor político y cultural en Castilla. ${ }^{6}$ La corona tampoco se ausentaría del encomio de un arte "para que se hiciesen los hombres letrados, lo qual parece que redunda en provecho universal de todos, y en ennoblecimiento de estos Reynos". ${ }^{7}$ Al mismo tiempo Isabel y Fernando fomentaron el mecenazgo, las ciencias y las letras, el asentamiento en la corte de humanistas, la reforma de universidades y centros de estudios y la industria tipográfica. Si bien, estas medidas favorables a la imprenta no deben llevarnos a pensar que mostraron una actitud semejante ante cualquier género de libros en circulación. Al revés, en momento alguno cejaron en la erradicación de los textos nocivos, vanos y supersticiosos, u opuestos a la religión y sus premisas gubernamentales. Ya en 1479 mandaron quemar, por su dañina y crítica visión de la confesión, el De confessione del teólogo Pedro Martínez de Osma (+1480). No obstante, fue la compleja aculturación de los musulmanes granadinos y de los judeoconversos el problema que acarreó el más atroz y famoso episodio de su onerosa biblioclastia.

La presencia de libros islámicos y hebreos representaba un grave obstáculo para la correcta cristianización de las mencionadas minorías étnico-religiosas. Con estas miras los monarcas prohibieron, bajo penas extremas, la traducción y posesión de versiones vernáculas de las Sagradas Escrituras. Como consecuencia de esta y otras medidas similares tuvieron lugar la quema de biblias hebraicas y otros libros judíos en 1490, y la de textos bíblicos en romance de Salamanca (1492) y Barcelona (1498). En 1500 el cardenal Cisneros (1436-1517) protagonizó en Granada las hogueras con miles de códices arábigos, sobre

\footnotetext{
${ }^{4}$ GARCÍA MÁRQUEZ, Gabriel. Del amor y otros demonios, Barcelona: Mondadori, 1994.

${ }^{5}$ MEXÍA, Pedro. Silva de varia lección, Sevilla: Fernando Díaz, 1587, p. 200.

6 De obligada consulta CÁTEDRA, Pedro y LÓPEZ-VIDRIERO, María Luisa. La imprenta y su impacto en Castilla, Salamanca: Compañía de Ediciones SEHL, 1998; y VALDEÓN BARUQUE, Julio (ed.), Arte y cultura en la época de Isabel la Católica, Valladolid: Instituto de Historia Simancas, 2003.

${ }^{7}$ Así lo anunciaron en las Cortes de Toledo de 1480. Toda la legislación sobre el libro en la España moderna la recopila Fermín de los Reyes Gómez. El libro en España y América. Legislación y censura (siglos XV-XVIII). Madrid: 2000, vol. II. Las leyes están ordenadas por año de emisión. A esta obra remito para la que sea citada a lo largo del texto, así evito la reiteración de notas a pie de página.
} 
todo coranes, una abominable tentación, decía el prelado, merecedora de tal fin. Aunque, parece, que perdonó el fuego a un lote de tratados médicos que trasladó al Colegio Mayor de Alcalá. ${ }^{8}$

La consecuencia última de toda esta sarta de prevenciones y temores fue la Pragmática de Toledo de 8 de junio de 1502. Inspirada en las normas dictadas por el papa Alejandro VI (1431-1503) a los arzobispos de Colonia, Magdeburgo, Maguncia y Tréveris, tras condenar las obras perversas, apócrifas y carentes de provecho, prohíbe la importación o impresión de los libros que no hubiesen obtenido una licencia real. Acto seguido conmina a los mercaderes-libreros del reino a presentar sus surtidos, al menos un listado, a alguno de los censores previstos, "algún letrado muy fiel y de buena conciencia de la Facultad que fueren los tales libros y lecturas"; entonces, los presidentes de las audiencias de Valladolid y Granada; los arzobispos de Toledo, Sevilla y Granada y los obispos de Burgos y Salamanca, las autoridades a las que se encomendó el examen de los libros y el dictamen sobre su utilidad. Se instituía así la censura previa de los textos por imprimir, que también conllevaba la compulsa de cualquier ejemplar de un título con su original examinado. ${ }^{9}$ Los infractores, libreros o impresores, perderían su mercadería gráfica, que habría de quemarse en la plaza pública del lugar donde se hallaren, además de pagar una multa y quedar excluidos del ejercicio de su profesión. La criba estipulada resultaba inexcusable porque los reyes habían sido informados de

\begin{abstract}
que vos los dichos libreros e imprimidores de los dichos moldes e mercaderes e factores de ellos aveys acostumbrado y acostumbrays de imprimir e traer a vender a estos nuestros reynos muchos libros de molde de muchas materias asi en latin como en romance e que muchos de ellos vienen faltos en las lecturas de que tratan, e otros viciosos, e otros apocrifos e reprobados, e otros nuevamente hechos de cosas vanas e supersticiosas e que a causa de ello han nacido algunos daños e inconvenientes en nuestros reynos. ${ }^{10}$
\end{abstract}

La emisión de esta ley originó que un importante número de obras de entretenimiento buscasen cobijo en las imprentas de Aragón, Navarra y Valencia. Sin embrago los Reyes Católicos no fueron los pioneros en poner en acción el método esbozado, sino el pontífice Alejandro VI, quien lo enunció en la bula Inter Multíplices del 1 de junio de 1501. Mas el mérito del primer edicto papal relativo a la imprenta, al estilo del anterior, se debe a otra bula Inter Multíplices (1487) de Inocencio VIII (1432-1492), aunque no será hasta el pontificado del papa Borja cuando arranque con certera decisión la represión literaria característica de la Iglesia romana, que se haría extensiva a toda la Cristiandad en la bula Inter Sollicitudines de León X (1475-1521), promulgada durante el V Concilio de Letrán de 1515. ${ }^{11}$ En Aragón venía siendo aplicado, por inquisidores y teólogos, desde finales de los años setenta del siglo XV; en Castilla, al igual, ya lo detectamos en la década de los noventa. ${ }^{12}$

El control del libro y la lectura, a pesar de lo expuesto, a la vista de los historiadores permaneció como un flanco poco desarrollado y a merced de las exigencias de instancias corporativas, mercantiles o eclesiásticos. Factores responsables de la precariedad legislativa y de la ausencia de un programa de

\footnotetext{
${ }^{8}$ Al hilo Peña, Manuel, "Libros y letras en tiempos de Isabel la Católica", en A. Moreno coord., Domus sapientiae. Fondos bibliográficos de la Universidad de Granada de la época de Isabel la Católica, Granada, 2004, pp. 13-41.

${ }^{9}$ Más en GARCÍA ORO, José. Los Reyes y los libros. La política libraria de la Corona en el Siglo de Oro (1475-1598). Madrid: Editorial Cisneros, 1995.

${ }_{11}^{10}$ En la aludida Pragmática de Toledo de 1502.

11 GONZÁLEZ SÁNCHEZ, Carlos A.. "Humanismo, libros y ciencia en la España de los Reyes Católicos", en GARCíA, M. y GONZÁLEZ, C. A. (eds.), Andalucía y Granada en tiempos de los Reyes Católicos. Sevilla: Universidad de Sevilla / Universidad de Granada, 2006, pp. 185-204..

12 GARCÍA ORO, José y PORTELA SILVA, Mํㅡㄹ José. La monarquía y los libros en el Siglo de Oro. Alcalá de Henares: Universidad de Alcalá de Henares, 2000.
} 
interdicción bien definido. La censura, como en el resto de Europa, la asumieron el Trono y el Altar dentro de un proceso de reformulación de sus poderes y sistemas de represión frente a los riesgos inherentes a la multiplicación de los impresos y la propagación de la herejía protestante. Una alianza del todo explícita en España desde el momento en el que la Inquisición tome cartas en el asunto, el instrumento de control más eficaz que, desde 1484, también asumió la vigilancia de los libros en circulación.

En definitiva, pocos negaban en las fechas que los malos libros sembraban errores, malas costumbres, subversión y, lo peor, la alteración de la visión de la realidad impuesta desde el poder. Secuelas que acusarían más los individuos de menor o nula preparación intelectual, los simples, a los que, como a niños, fácilmente podrían engañar, alejarlos de los ideales ortodoxos y entregarlos a mundos mentales subversivos capaces de poner en peligro el orden establecido. No en vano Alejandro VI, en la bula atrás mencionada, desconfía de los

pensamientos de la humana fragilidad que se inclinan más a lo malo que a lo bueno. De lo que resulta que, así como el arte impresora de escritos es utilísima para la fácil multiplicación de los libros probados y útiles, sería muy dañoso el que aquellos artífices utilizasen perversamente ese arte, imprimiendo por todas partes escritos perniciosos." ${ }^{13}$

No quedaba otro remedio, por tanto, que impedir la estampa de los escritos "opuestos a la fe católica, o que puedan verosímilmente producir escándalo en las mentes de los fieles". La lectura y el estudio, pues, debían ser en esencia un ejercicio sacro dirigido y encaminado a resolver misterios, edificante y redentor, cualidades asequibles mediante un programa didáctico que delimitara unos géneros literarios, unos gustos y unos discursos que, a su vez, cimentaran las actitudes, conductas y costumbres modélicas. No obstante, los peligros verdaderamente preocupantes aparecieron a raíz de la división de la Cristiandad que ocasionó la Reforma protestante. A partir de entonces católicos y luteranos se vieron como herejes irredentos y con unos idearios que, por los medios que fuere, intentaban difundir, o impedir su entrada, en los territorios de cada cual.

En aquella contienda ideológica es donde la imprenta desplegó en una primera oportunidad sus inmensas posibilidades y derivas propagandísticas ${ }^{14}$. Lutero en una fase ofensiva inicial utilizó los tórculos para ganar adeptos en la denominada guerra de los panfletos y, acto seguido, para difundir biblias en vernáculo y libros litúrgicos del credo reformado; pero, con el tiempo, le produjo el temor que le llevaría a la condena de los textos, según él, perniciosos y, tras los excesos de reformados radicales, a preferir la divulgación de las Sagradas Escrituras mediante la predicación antes que a través de la lectura individual de los fieles. Ya en 1520, en el Manifiesto a la nobleza cristiana de la nación alemana, escribió que "Por lo que se refiere a los libros teológicos, convendría asimismo reducir su número y seleccionar los mejores. Tampoco sería conveniente leer mucho, sino leer buenas cosas y leerlas con frecuencia, por poco que sea". $^{15}$

Lutero, pues, no fue tan proclive a la lectura popular como hace creer el tópico todavía vigente; es más, su actitud la compartieron Melanchthon, Zwinglio, Enrique VIII, Calvino y Bèze. A la postre, y como advierte J. F. Gilmont, "la Reforma lo cambió todo, y la Reforma no cambió nada", es decir, no transformó la relación de los creyentes con la cultura escrita ni impulsó la lectura de las masas más allá del uso intensivo

\footnotetext{
${ }^{13}$ REYES GÓMEZ, Fermín de los. op. cit., vol. II, p. 777.

${ }^{14}$ Al respecto, de sumo interés es el libro de EISENSTEIN, Elizabeth. La revolución de la imprenta en la Edad Moderna europea. Madrid: Akal, 1994.

${ }^{15}$ EGIDO, Teófanes, (ed.). Lutero. Obras. Salamanca: Ediciones Sígueme, 2001, p. 34.
} 
del catecismo y la liturgia. ${ }^{16} \mathrm{Al}$ igual que el catolicismo fomentó el libro y la lectura dentro de los límites de su ortodoxia; aunque se ha venido creyendo que la vigilancia de la imprenta y el control de la lectura eran exclusivos del mundo católico. Cierto es que en los estados fieles a Roma, España a la cabeza, la censura llegó a institucionalizarse de una forma que hoy nos resulta espectacular, pudiendo ser ésta, junto a la propaganda del bando contrario y al énfasis que Trento puso en el ritual exterior, el origen de un tópico que ha pasado de época en época hasta llegar a nuestros días.

Aun teniendo presente la parte de verdad de todo lugar común, la historiografía actual admite sin reparos que ambos contendientes, católicos y reformados, accionaron y potenciaron las cualidades pedagógicas y propagandísticas masivas de las prensas tipográficas, y, en concreto, una determinada literatura religiosa de gran consumo entre los distintos segmentos sociales. En este sentido, F. Bouza, aceptando los éxitos que las misiones populares contrarreformistas obtuvieron mediante recursos orales y visuales, considera imprescindible ahondar no sólo en las restricciones de las autoridades sino también en el protagonismo que la imprenta ejerció en el adoctrinamiento de la opinión pública en la Europa del Antiguo Régimen. ${ }^{17}$

El descubrimiento de América sin duda fue el suceso por antonomasia en la España de los Reyes Católicos, el mayor de todos los tiempos hasta 1492, algo inaudito y de consecuencias imprevisibles. El logro de una época, el Renacimiento, ávida de cambios, entusiasmada con sus invenciones, las novedades en cierne y las ansias de saber más sobre el universo y lo desconocido. ${ }^{18}$ La escritura, impresa o manual, tuvo un protagonismo decisivo entre los descubridores y conquistadores del Nuevo Mundo, y todavía más en la aculturación, u occidentalización, de las gentes allí encontradas, uno de los fines prioritarios plasmados en las bulas pontificias que adjudicaron la propiedad de aquellos confines increíbles. El clima profético y apocalíptico latente en la Europa de comienzos del Quinientos, hizo que los primeros frailes evangelizadores que allí arribaron, interpretaran la conversión al cristianismo de los indios como un indicio genuino del advenimiento del Milenio, cual la recompensa divina por la división de la Cristiandad acaecida a raíz de la aparición del protestantismo. Los franciscanos observantes asentados en las Antillas y en la recién inaugurada Nueva España, como las demás órdenes mendicantes involucradas en dicha empresa desde el principio, albergaban la esperanza del renacer de la Iglesia primitiva en América, sin los vicios, excesos y corrupciones que la habían llevado al marasmo y la decadencia. ${ }^{19}$ En estas lides, el franciscano y erasmista fray Juan de Zumárraga (1468-1548), arzobispo de México, el primero, desde 1528, compuso un catecismo para indios con un lenguaje sencillo y bíblico. Mientras que en Michoacán, el obispo Vasco de Quiroga (1470-1565), organizó dos comunidades indígenas según el modelo plasmado en la Utopía de Tomás Moro.

Zumárraga, hacia 1533, elevó a la consideración del Consejo de Indias la conveniencia de establecer una imprenta y un molino de papel en la capital del virreinato novohispano, recursos esenciales para una eficiente evangelización. Tras conseguir la adhesión al proyecto del virrey Antonio de Mendoza, el

\footnotetext{
${ }^{16}$ GILMONT, Jean F.. "Reformas protestantes y lectura", en CHARTIER, R. y CAVALLO, G. (dirs.). Historia de la lectura en el mundo occidental. Madrid: Taurus, 1997, pp. 329-366.

${ }^{17}$ Una ingeniosa muestra nos la ofrece BOUZA, Fernando. "Contrarreforma y tipografía. ¿Nada más que rosarios en sus manos". Cuadernos de Historia Moderna. 16, 1995, pp. 73-87.

${ }^{18}$ Una vision de conjunto de la época en GARCíA DE LA CONCHA, Víctor (coord.). La cultura del Renacimiento (14801580). Historia de España Ramón Menéndez Pidal. vol. 21. Madrid: Espasa-Calpe, 1999; y BELL, Aubrey. El Renacimiento español. Málaga: Universidad de Málaga, 2004.

19 Sobre esta temática el clásico de PHELAN, John L.. El reino milenario de los franciscanos en el Nuevo Mundo. México: Universidad Autónoma de México, 1972; y BRADING, David A.. Mito y profecía en la historia de México. México: Vuelta, 1989.
} 
afamado impresor de Sevilla Juan Cromberger, animado por ambos, decidió abrir una sucursal de su oficina en México. ${ }^{20}$ Donde en 1539 vio la luz el primer impreso americano: la Breve y más compemdiosa doctrina christiana en lengua mexicana y castellana, un recurso de suma utilidad para los afanes misionales en acción, a cuyo servicio se puso la tipografía, el instrumento que terminaría consolidando la identificación de la lectura y la escritura alfabética con la religión cristiana. ${ }^{21}$

La cristianización de las Indias, en esta fase inicial, pretendió imbuir a los indios -mediante la memoria histórica y el escrito- en la lengua castellana y, en segunda instancia y en casos determinados, en la latina. Los misioneros vieron en la cultura escrita el mejor medio para erradicar de la conciencia de los naturales de las Indias su pasado ancestral; así como para controlar las dependencias y relaciones entre las dos civilizaciones en contacto. Si bien, este método alfabetizador y doctrinante chocó contra unos obstáculos difíciles de superar, el más complicado, el imaginario de unas gentes inmersas en una tradición oral y pictográfica, icónico-visual. Por ello las intenciones de los franciscanos a la hora de dar a los hijos de la nobleza indígena una educación letrada propia de minorías en Europa, tuvieron que ser abandonadas o, a lo sumo, restringidas a casos selectivos. El elevado coste financiero de tan magno cometido educativo, forzó la inversión de los términos del plan primigenio, es decir, resultaría menos complicado y gravoso, además de resolutivo, que los frailes aprendieran las lenguas nativas. ${ }^{22}$

Se pensó que este trueque de estrategias no influiría de manera decisiva en el resultado final de la catequesis. A partir de aquí la hispanización de las Indias empezó a contemplarse como un proyecto a largo plazo, fruto del paso del tiempo, que la experiencia demostró inviable; al menos mientras las comunidades indígenas siguieran existiendo separadas de las de los españoles. La llegada de los jesuitas al Nuevo Continente, en 1572, en medio de un panorama eclesiástico e ideológico muy distinto, pudo significar una cierta vuelta a los postulados franciscanos, augurio de las futuras reducciones. El provincial mexicano Pedro Sánchez, en la congregación de 1577, tras discernir la pusilanimidad y endeble inteligencia de los indios, estimó que

\begin{abstract}
sería lo más conveniente hazer collegios de niños indios, hijos de los principales, de buena índole y abilidad, y que biviesen en nuestros collegios para los instruir en toda buena policía y cristianas costumbres, enseñándoles leer y escribir y doctrina cristiana, para que si Nuestro Señor hiciese dellos a algunos capaces de la perfección, fuesen estos dignos ministros de su nación; y haría uno dellos más que cientos de nosotros. ${ }^{23}$
\end{abstract}

Nótese el énfasis, contrarreformista, puesto en la "buena índole", "buena policía" y "cristianas costumbres" y, en última instancia, en las posibilidades y previsibles logros del sistema esbozado. Porque a medida que fue desarrollándose la colonización, y ante el ímpetu de la Reforma y la complejidad humana que irá adquiriendo la nueva sociedad indiana, la meta de una iglesia profética y evangélica se dejó de lado. Así, la aculturación se adaptó los planteamientos intransigentes del estado y la jerarquía eclesiástica, radicalizados al ritmo de los acontecimientos europeos, especialmente después de Trento. Momento en el

${ }^{20}$ GRIFFIN, Clive. Los Cromberger. La historia de una imprenta del siglo XVI en Sevilla y México. Madrid: Cultura Hispánica, 1991; WAGNER, Klaus. "La imprenta. De Gutenberg a las tipografías hispanas de América", en PEÑA, M., RUIZ, P. y SOLANA, J. (coords.). La cultura del libro en la Edad Moderna. Andalucía y América. Córdoba: Universidad de Córdoba, 2001, pp. 1-20.

${ }^{21}$ CHOCANO MENA, Magdalena. La fortaleza docta. Elite letrada y dominación social en el México colonial (siglos XVIXVII). Barcelona: Edicions Bellaterra, 2000, p. 52.

22 Esta cuestión la abordé en Los mundos del libro. Medios de difusión de la cultura occidental en las Indias de los siglos XVI y XVII,. Sevilla: Universidad de Sevilla, 1999.

${ }^{23}$ Félix Zubillaga , ed., Monumenta Mexicana, Roma, 1956-1976, vol. I, doc. 112, p. 318. 
que la labor misional, en ambas orillas del Océano, adquiere un acusado matiz disciplinante, mediante la combinación de una propaganda religiosa militante y la difusión de modelos piadosos, políticos y comunitarios ideales. ${ }^{24}$ En esta tesitura, la religión oficial, y sus derivados culturales, fue el más importante factor de integración en la sociedad, y de la homogeneidad de los esquemas mentales impuestos desde arriba. ${ }^{25}$ Con el fin de conservar la pureza de estos principios, las autoridades, temerosos de la fuerza ideológica de los libros, extremaron el control de las ideas escritas, la censura de la producción tipográfica y de todo material impreso en circulación.

\section{Laberintos de la ficción poética}

La corona española tampoco dejó de percibir la creciente popularidad de las narraciones caballerescas, un tipo de literatura fantástica y de aventuras desde tiempo atrás considerada obscena e inapropiada, especialmente para los jóvenes. Dichos libros, pese a la condena estatal, de moralistas e intelectuales, no fueron objeto de persecución activa, salvo algún título concreto. Pero a toda costa se quiso impedir su circulación y lectura, porque se temía que las gentes creyeran y reprodujeran al pie de la letra las hazañas y conductas de sus protagonistas ficticios; y, peor aun, las maravillas y portentos de unos relatos impíos y alejados de la veracidad histórica. Así, estos cuentos podrían ser un peligroso rival de la Biblia, texto del mismo modo poblado eventos sobrenaturales, los del poder de Dios y de nadie más. De ahí que al precio que fuere había que evitar que pasaran a América, donde podrían estorbar en grado sumo la conversión al cristianismo de los indios. Había que velar por la integridad moral de los dominios ultramarinos eliminando cualquier discurso nocivo o que pudiere corromper su modelo colonizador.

En 1506 parece que el rey Fernando, entre las instrucciones dictó para el buen gobierno de las Indias, prohibió llevar allí libros profanos, frívolos o inmorales. Como muchos teólogos, moralistas, humanistas e intelectuales coetáneos, pensaba que allí pondrían en peligro la autoridad suprema de las Sagradas Escrituras y, en consecuencia, la incipiente cristianización de los aborígenes, de gentes apreciadas débiles en conciencia e incapaces de distinguir entre fábula y revelación, es decir, dispuestas a otorgar idéntica credibilidad a cualquier texto impreso, pues, estando inmersas en una vivencia espiritual y material que interpretaban a través de mitos y ritos mágicos, de igual forma interpretarían los no menos fantásticos dogmas religiosos cristianos que el supercherías de los relatos de aventuras, actitud que les podría llevar a seguir las conductas de los héroes imaginarios y a abandonar la religión. En lo sucesivo, la certeza de la creciente recepción y difusión de las llamadas historias mentirosas impulsó una serie de medidas legales para cerrarles el paso a Indias.

El 4 de abril de 1531 en Ocaña reina Juana, madre de Carlos V, informada de la cantidad de libros que "pasan a las Indias muchos de Romance de ystorias vanas y de profanidad commo amadis, mal exercicio para los yndios e cosa en que no es bien se ocupen ni lean"; ordenó a los oficiales de la Casa de la Contratación no consentir a persona alguna

\footnotetext{
${ }^{24}$ PROSPERI, Véase Adriano. "L'Europa cristiana e il mondo: alle origini dell'idea de missione”, Dimensioni e problemi della recerca storica, 2, 1992, pp. 189-220; y su El Concilio de Trento: una introducción histórica. Valladolid: Junta de Castilla y León, 2008.

${ }^{25}$ Quiero destacar dos estudios interesantes sobre el tema en la Europa de la época. Uno, la obra colectiva: La censura libraria nell'Europa del secolo XVI, U. Rozzo ed., Udine, Forum, 1997; y las de INFELISE, Mario: I libri proibiti da Gutenberg all'Encyclopédie. Bari: Laterza, 1999; y MEREU, Italo: Historia de la intolerancia en Europa. Barcelona: Paidós, 2003.
} 
pasar a las Indias libros ningunos de historias y cosas profanas, salvo tocante a la religión cristiana e de virtud en que se ejerciten y ocupen los dichos indios e los otros pobladores de las dichas Indias, porque a otra cosa no se ha de dar lugar.

Sin embargo, y dada la reiteración de estas prescripciones en adelante, los efectos de las leyes no fueron los esperados. La norma, salvo la poco frecuente confiscación de los libros, no preveía castigo ejemplar para los infractores; nadie fue azotado, desterrado, encarcelado, enviado a galeras o multado severamente por tener o vender obras de ficción caballeresca, ni éstas, a excepción de alguna-Amadís en 1559- de notable inmoralidad, fueron a parar al Índice de libros prohibidos. Sólo hay que repasar los negocios de los Cromberger, los mayores exportadores tipográficos entre España y las Indias de 1525 a 1540, para comprobar la existencia de miles de impresos caballerescos y de otras ficciones en sus surtidos; o sea, una cuantiosa inversión de dinero que, según Leonard, estaba destinada a la demanda americana, bien calculada y conocida. ${ }^{26}$ Mayor era, por tanto, el grueso de los beneficios económicos y el placer de la lectura o audición de las aventuras imaginarias que el perjuicio consecuente de la omisión de la normativa. Como afirma Weber, las reglas se obedecen cuando el interés de su obediencia es superior al de su desobediencia. Obviamente no de menor influencia debieron ser las dificultades que el rudimentario aparato estatal tuvo para abrir ágiles vías de comunicación de la ley entre la población y a la hora de encontrar actuaciones fiables que garantizaran su cumplimiento.

No es baladí que, de nuevo, el 13 de septiembre de 1543 el príncipe Felipe exigiera mayor atención y celo en la resolución del problema, que justifica de la manera siguiente:

\begin{abstract}
los indios que supieren leer, dándose a ellos, dexarán los libros de buena y sana doctrina y leyendo los de mentirosas ystorias aprenderán en ellos malas costumbres y vicios: y demás desto de que sepan que aquellos libros de historias vanas han sido compuestos sin aver passado ansí, podría ser que perdiessen la autoridad y crédito de la Sagrada Escriptura, y otros libros de Doctores, creyendo como gente no arraigada en la fee, que todos nuestros libros eran de una auctoridad, y manera. ...vos mando no consyntáis ni deys lugar, que en essa tierra se vendan ni ayan libros algunos de los susodichos, ni que se traygan de nuevo a ella, y proveays que ningún español los tenga en su casa, ni que Indio alguno lea en ellos...
\end{abstract}

Su argumento, sobrado en claridad, no precisa de mayores explicaciones, aunque es necesario destacar la conciencia del heredero real de ser sumamente atractivo, maléfico y subyugante a los aficionados el contenido de esas retóricas imaginarias, a las que se le otorga un poder extraordinario capaz de mudar las costumbres de los hombres; por ello, el futuro Felipe II centra los efectos perversos en la sustitución de la doctrina por la emulación de los héroes y su mal ejemplo. Téngase en cuenta que el providencialismo, los milagros, las acciones portentosas demoníacas y otras maravillas, elementos cotidianos cuya creencia fomentaba la Iglesia, estaban a la orden del día; no siendo insólito, pues, que les atribuyeran los hechos sobrenaturales que adornan el devenir de los héroes literarios. Los moralistas, particularmente después de Trento, estimaron que la ficción poética, cruzando lo divino y lo humano, desafiaba y tendía una trampa mortífera a lo sagrado; de ahí que tampoco toleren la naturaleza desacralizada la poesía y la comedia. ${ }^{27}$ Ambas, creaciones literarias del mismo modo incompatibles con el

\footnotetext{
${ }^{26}$ Se trata del inventario del fondo de Juan Cromberger realizado en 1540, donde se contabilizan casi 9.000 ejemplares. VÉASE GRIFFIN, Clive. "El inventario del almacén de libros del impresor Juan Cromberger: Sevilla, 1540", en CÁTEDRA, P. M. y LÓPEZ VIDRIERO, Mํㅡ. L. (dirs.). El Libro Antiguo Español, IV: Coleccionismo y Bibliotecas (siglos XV-XVIII). Salamanca: Universida de Salamanca, 1998, pp. 257-373; y LEONARD, Irving A.. Los libros de conquistador. México: Fondo de Cultura Económica, 1979, p. 108.

${ }^{27}$ Ellos definían la ficción de acuerdo con concepto aristotélico de poiesis y no por su forma externa, en prosa o en
} 
cristianismo y desconectadas de cualquier acontecimiento con relevancia histórica. En definitiva, no entendían la ficción por la ficción ${ }^{28}$.

Sin embargo la ley anterior, como todas las que se dictaron durante los siglos XVI y XVII, tampoco logró el remedio deseado. ${ }^{29}$ Por ello el emperador Carlos en 1550 hizo obligatorio que cualquier persona "cuando hubieren de llevar a las Indias algunos libros de los permitidos, los hagan registrar cada uno, declarando la materia de que trata, y no se registren por mayor". Hasta entonces los libros se registraban en la Contratación a bulto sin otra aclaración, excepto su valor para calcular el impuesto correspondiente. Además, en adelante los implicados tendrían que presentar dichas listas en la sede de la Inquisición en Sevilla, donde los calificadores, tras examinarlas y comprobar que su contenido coincidía con lo dispuesto a embarcar, otorgaban o no el permiso de salida.

Dos años más tarde, en las Ordenanzas de la Casa de la Contratación de 1552, se delimitan las temáticas a las que se debía vetar o facilitar su envío a las Indias: "historias fingidas, profanas, ni libros de materias deshonestas, salvo libros tocantes a la religion christiana, y de virtud, en que se ocupen y exerciten los Indios y los otros pobladores de las dichas Indias". ${ }^{30}$ Este cambio en la política imperial también se debe al fracaso de la actitud de concordia con los luteranos hasta mediado de los años cuarenta del Quinientos. A la postre, el avance del credo protestante y la revitalización que la Reforma experimentó con el calvinismo, radicalizaría aun más el control ideológico activado en la Monarquía Hispánica. Sobre todo en Sevilla, cuyo puerto era el único habilitado en la península para el tráfico, humano y material, con América; circunstancia que predispuso en los gobernantes la puesta en marcha de unos mecanismos de vigilancia mucho más rigurosos. En aquella urbe sólo el Amadís tuvo 28 ediciones entre 1500 y 1570.

La diatriba en torno a los relatos de caballería alcanzó un punto culminante en 1555, fecha en la que los procuradores de las Cortes castellanas reunidas en Valladolid pidieron al rey la completa prohibición de su publicación, venta y lectura. La petición la defendieron con el argumento que va a continuación:

\begin{abstract}
Otrosí, dezimos que está muy notorio el daño que en estos reynos ha hecho y haze a hombres mozos y doncellas, e a otros géneros de gentes leer libros de mentiras y vanidades como son Amadís y todos los libros que después dél se han fingido de su calidad y lectura...porque como los mancebos y donzellas por su ociosidad principalmente se ocupan en aquello, desvanécense y aficiónanse en cierta manera a los casos que leen en aquellos libros haber acontescido, ansí de amores como de armas y otras vanidades, y aficionados quando se ofrece algún caso semejante danse a él más a rienda suelta que si no lo oviesen leydo. ${ }^{31}$
\end{abstract}

Bien puede apreciarse que los procuradores se muestran temerosos del valor paradigmático del comportamiento de los caballeros andantes, en el amor y en las armas, para la gente joven del siglo. En parte no les faltó razón, porque Amadís y sus émulos, de acuerdo a la transformación que experimentó un género heredado del Medievo, fue algo más que el mejor relato de aventuras fantásticas. Tan exitoso título hizo las veces de un auténtico manual de cortesanía en el que la aristocracia vio representadas sus

verso. Por ello tenían en la misma consideración a los libros de caballería, las novelas de pastores, las sentimentales, la poesía y comedias profanas; véase BAKER, E.. La biblioteca de Don Quijote. Madrid: Marcial Pons, 1997, p. 82.

${ }^{28}$ En esta línea está el espléndido libro de BANDERA, Cesáreo. El juego sagrado: lo sagrado y el origen de la literatura moderna de ficción. Sevilla: Universidad de Sevilla, 1997, p. 36.

${ }^{29}$ Aparte de Leonard y Torre Revello, buenos ensayos sobre la polémica moralizante en torno a los relatos de ficción es la de IFE, Barry: Lectura y ficción en el Siglo de Oro, Barcelona: Crítica, 1991. También el de ADORNO, Rolena: "Literary production and suppression: reading and writing about Amerindians in colonial Spanish America", Dispositio, 11, 1986, pp. 1-25, y LÓPEZ, François: "Las malas lecturas. Apuntes para una historia de lo novelesco", Bulletin Hispanique, 100-2, 1998, 475-514.

${ }^{30}$ En TORRE REVELLO, José. El libro, la imprenta y el periodismo en América durante la dominación española. Buenos Aires: Jacobo Peuser, 1940, p. 38.

${ }^{31}$ Es útil MOLL, Jaime: "Libro y sociedad en la España moderna". Bulletin Hispanique, 99-1, 1997, pp. 7-17. 
conductas y formas de relación social ideales. ${ }^{32}$ La demanda de las Cortes de Valladolid, por lo demás, continúa aludiendo a la marginación en que caerá la doctrina religiosa y a la necesidad de prohibir y eliminar los libros mentirosos.

La actitud de los reyes y el resto de los hombres de estado respecto a los libros de aventuras consecuencia del efecto multiplicador de la imprenta-, no es más que el fiel reflejo de la opinión que prevaleció entre un destacado e influyente grupo de escritores religiosos, la mayoría ascético-espirituales, quienes marcaban los cauces de la moral en la España del siglo XVI, sobre todo en su segunda mitad. Atentos a la competencia que la literatura de entretenimiento en general hacía a sus tratados devotos y a los asuntos del credo, y alertados frente al número de casos de lectores que afirmaban la autenticidad de unas tramas ficticias, quisieron marginar no sólo los textos caballerescos, y toda la invención literaria, sino también la poesía cancioneril, las composiciones teatrales y cualquier discurso profano, categorías estas últimas para las que, al igual, pedían control los procuradores de Valladolid en 1555. En general, y según pone de relieve B. Ife utilizando el símil de la expulsión de los poetas de la república platónica, todos recriminan a la ficción el dejar de lado, mediante el mal ejemplo, las virtudes religiosas edificantes a cambio del disfrute de experiencias ajenas, la falsificación de la realidad y el menosprecio a la autoridad de la verdad, o lo que es lo mismo, afianzar unas mentiras opuestas a la formación moral del espíritu humano. ${ }^{33}$

Arias Montano, Antonio de Guevara, Pedro Malón de Chaide, fray Luis de Granada, Gaspar de Astete, Melchor Cano, Diego de Estella, Esteban de Salazar y un largo etcétera, todos grandes ventas durante la Contrarreforma, lanzaron los muy conocidos dardos envenenados (pestilencia infame, cuchillo, putrefacción, sepulcros malolientes) contra un género que consideraban de nefastas consecuencias para los fieles, preferentemente para el pueblo llano. Gente acostumbrada a hacer de la lectura un acto de fe, a leer u oír un cuento fantástico literalmente, olvidando así su carácter novelesco y, en última instancia, incapaz de distinguir la invención de la realidad, dos polos sin frontera precisa, casi imperceptible, en aquel tiempo. En este sentido Alejo Venegas (c.1497-1562), autor laico del mejor ars moriendi de la época de Carlos V, estaba convencido de haber escrito un curioso tratado sobre los libros con el fin de distinguir los malos, y prevenir a los lectores de sus terribles efectos; de esta manera lo expresa:

es cosa muy convenible a razón que los libros que son corruptela de las buenas costumbres se quiten de en medio. Porque es cierto que como si fuessen personas han de hablar a sus solas con la gente vulgar. La qual como no sepa distinguir lo aparente de lo verdadero piensa que qualquier libro impresso tiene auctoridad para que le crean lo que dixere. ${ }^{34}$

Apréciese cómo incide en la lectura solitaria y en el axioma leer igual a creer. Muy similar es el planteamiento del maestro Pero Mexía, preocupado por tanta insidia "contagiosa y dañosa de la república" como Amadises, Lisuartes y Clarianes, Esplandianes, Floranises, Lepolemos, Floriseles, cuyos sucesos demasiados creían "passaron assí como las leen y oyen, siendo como son las más dellas cosas malas, profanas y deshonestas"; lamentando la "licencia demasiada en imprimir libros de poco fructo y provecho, de fábulas y mentiras, que mejor fuera no aver molde para ellos, porque destruyen y cansan los ingenios y los apartan de la buena y sana leción y estudio". ${ }^{35}$

\footnotetext{
32 VÉASE AVALLE-ARCE, Juan B.. "Características generales del Renacimiento literario", en ,DíEZ BORQUE J. Mํa. (coord.). Historia de la literatura española. Madrid: Taurus, 1980, vol. II, pp. 13-48.

${ }^{33}$ Indispensable IFE, Barry, op. cit, pp. 11-44; y LEWIS, Charles S., De este y otros mundos. Ensayos sobre literatura fantástica. Barcelona: Alba Editorial, 2004.

${ }^{34}$ VENEGAS, Alejo, Declaración de la diferencia de libros que ay en el universo.... Toledo: Juan de Ayala, 1546, p. 2.

${ }^{35}$ Pero Mexía. Historia Imperial y Cesárea. Sevilla: Sebastián Trujillo, 1564, p. 225.
} 
La lectura literal de las ficciones, narraciones de naturaleza alegórica, pueden ofrecer a los lectores una explicación subyacente del mundo en el que viven y hacerles creer que, de ocupar el sitio de sus personajes, habrían tenido la oportunidad de vivir las mismas experiencias. Esta es la forma de lectura que llevó a don Quijote a la locura, a invertir el orden de las cosas. La literalidad, el núcleo del conflicto, procedía de una tradición oral que, para perpetuarla, se representó en los libros; pero de paso, y según advierte D. R. Olson, dicha representación iba a permitir controlar la forma en la que los textos debían interpretarse y recibirse ${ }^{36}$. Así empezarían a hacerlo, y lo estamos viendo, los hombres de la Alta Modernidad gracias a la imprenta. No gratuitamente el texto creativo, dicen Eco y Calvino, es una máquina perezosa que requiere la cooperación activa e interpretativa de un lector modelo atento, que en pos del placer de la lectura, rellena a rellenar los espacios en blanco, lo no dicho, que la fábula promueve ${ }^{37}$.

Fray Diego de Estella (1524-1578) llama cronistas del demonio a sus autores, a la vez que advierte a los aficionados al género que

Los puercos desprecian las rosas y aman el estiercol. Assí los hombres sensuales y vanos aman las hablillas y libros prophanos del mundo... Huye pues del veneno de los libros prophanos como de manifiesta pestilencia, y ama la leción de los libros santos y devotos: porque con la buena y saludable doctrina sea tu espíritu recreado, y sepas lo que debes hazer para alcançar la vida eterna. ${ }^{38}$

La condena del egregio franciscano, en la que también alude al antídoto de tan maléfica colección de letras, no dista mucho de la de su correligionario Francisco Ortiz Lucio (1550-1651):

es muy inútil y de poco provecho, la lección de las Celestinas, Dianas, Boscanes, Amadises, Esplandianes y otros libros llenos de portentosas mentiras. Y del abuso de Satanás con estos libros ha introducido, no se grangea cosa, sino que la tierna doncella, y mancebo, hagan de tal lección, un tizón y fuego, y soplo incentivo de torpeza, donde enciendan sus desseos y apetitos de liviandad, y estos se vayan cuando poco a poco, hasta experimentar por obra, lo que por palabra leen. ${ }^{39}$

En otra obra, incidiendo en el remedio, Ortiz Lucio dirá que "los buenos christianos queman los libros prophanos, y leen los devotos llenos de espíritu y fuerça. ${ }^{40}$ El dominico Juan de los Ángeles (15361609), al igual e imitando la disposición anímica de muchos de sus compañeros en los tratados ascéticos, justificaba la escritura de sus Triunfos del amor de Dios considerando

quan amortiguado o muerto está el fuego celestial en los coraçones de los hombres, y quan encendido el sensual y de mundo, porque tiene Satanás infinitos ministros, que no ossan de echar leña a carretadas, de malas palabras, de malos consejos de infernales desseos, de consideraciones torpes, escribiendo para esto libros de amores, sonetos, lyras y otras canciones prophanas en mucho detrimento de las almas.

\footnotetext{
${ }^{36}$ OLSON, David R., El mundo sobre el papel. El impacto de la escritura y la lectura en la estructura del conocimiento. Barcelona: Gedisa, 1998, p. 198.

${ }^{37} \mathrm{ECO}$, Umberto. Lector in fábula. Barcelona: Lumen, 1999, p. 39. Italo Calvino pone el método en práctica en su libro Si una noche de invierno un viajero. Madrid: Siruela, 1999.

${ }^{38}$ ESTELLA, Diego de. Primera parte del libro de la vanidad del mundo. Alcalá de Henares: Juan Gracián, 1597, p. 97.

${ }^{39}$ ORTIZ LUCIO, Francisco, Libro intitulado lardín de amores sanctos.... Alcalá de Henares: Juan Íñiguez de Lequerica, 1589. Fragmento extraído del prólogo al lector.

${ }^{40}$ ORTIZ LUCIO, Francisco. Summa de summas, de avisos y amonestaciones..., Alcalá de Henares: Juan Íñiguez de Lequerica, 1595, p. 5.

${ }^{41}$ ÁNGELES, Juan de los. Triunphos del Amor de Dios..., Medina del Campo: Francisco del Canto, 1589, p. 267.
} 
Como puede verse, los tres espirituales citados, y los demás, claman especialmente contra los ingredientes erótico-amorosos y pasionales de las creaciones literarias en cuestión, o sea, contra la acentuada sensualidad que impregna las relaciones humanas de los personajes centrales. Esta forma de resolver los argumentos y de captar atenciones mediante recursos emocionales, fue drásticamente condenada porque sus detractores veían en ella motivos de sobra para incitar a los jóvenes y llevarles a emular un lenguaje perverso y unas conductas deshonestas y alejadas del deber cristiano. Mas no parece que las reprobaciones de los autores religiosos, ni las censuras eclesiásticas o los decretos del Concilio de Trento, refrenaran la manifestación del deseo amoroso característica de esta etapa inicial de la novela moderna. ${ }^{42}$

Desde esta perspectiva no resulta extraño que los gobernantes se movieran en función de un clima discrepante con determinados géneros literarios en auge y del gusto de un nutrido número de personas. Incluso, el humanismo cristiano, anteponiendo la educación y el aprovechamiento moral al divertimento, abogó por un ideal verosímil y ajustado a la historia. ${ }^{43}$ El rechazo de la narrativa caballeresca y sentimental y de la poesía cancioneril es propio del erasmismo español, movimiento intelectual en el que sobresale la crítica radical de Vives, humanista que atribuía la popularidad de dichas narraciones al énfasis puesto en lo sensual, a las vanas fábulas y a las evocaciones licenciosas. ${ }^{44}$ Para contrarrestarlas el valenciano aconseja la vertiente moralizante de las vidas ejemplares, los apotegmas de grandes hombres (Valerio Máximo, Erasmo, Plutarco, etc.) y, en general, toda la prosa didáctica o misceláneas divulgativas de temas científicotécnicos y cuentos folclóricos, en la que tuvieron un éxito duradero las obras de fray Antonio de Guevara (1480-1545) y Pedro Mexía.

Si bien, la condena de los moralistas no logró disminuir en mínima medida la popularidad de los géneros de ficción por excelencia a lo largo del siglo XVI, con toda probabilidad también en el primer tercio del XVII; es más, como suele suceder en estos casos, pudo haber originado el efecto contrario y acrecentar el morbo y la atracción por la literatura denostada. Pero no menos significativo fue el sistema normativo y didáctico que desencadenó, responsable de la difusión de un estado de opinión al que se adhirieron, siquiera en apariencia externa y por el prestigio moral y social de las voces discrepantes, los intelectuales y, en general, la elite familiarizada con el libro. La interdicción activada, al igual que en la actualidad, propició que cualquier escritor o lector que se preciara y quisiera ser aceptado, o con voluntad de integrarse, en determinados círculos de solvencia repudiara los libros fantásticos y, en cambio, mostrara en sus anaqueles sólo lo que estaba a bien poseer y aceptado en la norma moral y cultural vigente, aunque en la intimidad fuera un devorador de la caballeresca o de las novelas sentimentales que escondía en el arcón de un rincón oculto. Al final se fue perpetuando un tópico que duraría hasta, al menos, el siglo XVIII.

Muy explícito es el testimonio de Bartolomé Álvarez, un doctrinero de la Audiencia de Charcas del Perú autor de un memorial, escrito en 1588 y dirigido a Felipe II, en el que consternado y con amargura lamenta las dañinas secuelas que la caballeresca seguía perpetuando en los indios. Por ello ruega al rey la intervención de la Inquisición en el seguimiento y castigo de sus irredentas conductas idolátricas, esgrimiendo el escaso alcance de la misión después de cincuenta años. Según él, los indígenas alfabetizados, dada su maligna inclinación congénita, antes preferían los cuentos de caballeros andantes

\footnotetext{
${ }^{42}$ Esta es la postura que defiende LÓPEZ, François. "Las malas lecturas. Apuntes para una historia de lo novelesco". Bulletin Hispanique, 100- 2, 1998, pp. 475-514.

43 CASTRO DÍAZ, Antonio, "Prosa y pensamiento", en Historia y crítica de la literatura española. Rico, F. (dir.), Barcelona: Crítica, 1993, vol. II, pp. 156-172.

44 Imprescindible BATAILLON, Marcel. Erasmo y España. México: FCE, 1983, p. 616.
} 
que los del credo católico, incluso afirma con énfasis que de preguntarles "si vieron en aquella sazón a Reinaldos de Montalbán que estaba en aquel acto, y dicen que sí y dan las señas; y si vieron al Cid Ruy Díaz, y dicen que sí y lo que estaba haciendo". "Estas tretas, y la propensión a la herejía de los naturales, hacen temer al misionero que

Si los luteranos diesen en imaginar que los indios saben leer, y son amigos de estas bachillerías y bellaquerías, para enviarles libros secretos. Que si una vez los diesen y los indios por ellos conociesen las libertades de los herejes, no sería menester más para la herejía, que son en suciedades conformes a sus idolatrías y pecados, para que perpetuamente no se desarraigase dellos la secta que se le sembrase, sería recibida con brevedad y contento. ${ }^{46}$

Ahogado en pesimismo y resignación concluye: “¿cómo puede ser bueno para una gente tan incapaz, de rondón entrarles persuadiendo por unos medios tan dificultosos, para hacer entender a las bestias cómo se han de conocer margaritas preciosas? ${ }^{47}$

Mandatarios ni moralistas quisieron entender, al menos de forma expresa, cómo un importante número y variedad de lectores y oyentes se divertían y entretenían con los libros en cierne, unas invenciones que los sumergía en un universo de ensueño alejado del verdadero, pero sin desvincularlos del todo del mismo. ${ }^{48}$ La caballeresca, en concreto, los acercaba a un mundo más primitivo y heroico que, por haber perdido su vigencia, les parecía más atractivo. Una idealización de otra realidad pasada o imaginaria, que evadían a sus consumidores de la conflictiva edad en la que vivían, plagada de miserias espirituales y materiales. Sobre la fantasía, en suma, como ocurre hoy día, proyectaban los anhelos y temores derivados del vertiginoso cúmulo de novedades que impactó en la sociedad del Renacimiento; primicias difíciles de asumir con los referentes simbólicos de la cultura de la época. De ahí que sin la perspectiva temporal necesaria, sin una clara noción de diferencia entre lo racional e irracional, se vuelvan la vista atrás y hacia lo ilusorio, en busca de estímulos y del sentido de la realidad. La ficción siempre compensa las frustraciones de nuestras vidas.

Al hilo es en grado sumo esclarecedora la docta opinión, contraria a las novedades de la mente, del egregio Martín de Azpilcueta (1492-1586), el teólogo moralista católico de mayor circulación durante la alta Modernidad:

Lo novo fue el inicio de la curiosidad, aunque no es hija de la vanagloria, pero parécese mucho con el vicio de la invención, hija segunda suya. Y que es vicio que inclina a querer desordenadamente saber sobrado, o como no deve, y que siempre es pecado, a lo menos venial... ${ }^{4}$.

La búsqueda de la novedad es vista como puerta abierta al miedo, la soberbia, la codicia y, en última instancia, a sentimientos de inestabilidad y a una curiosidad desmedida de efectos imponderables. Ello explica, sobre todo desde mediados del Quinientos, las resistencias de los guardianes de la ortodoxia y la tradición hacia cualquier innovación que pudiera alterar el orden de las cosas y el milagroso equilibrio

${ }^{45}$ ÁLVAREZ, Bartolomé, De las costumbres y conversión de los indios del Perú. Memorial a Felipe Il (1588), edic. de MARTÍN, Maㅡ C., VILLARÍAS, J. J. y DEL PINO, F.. Madrid: Ediciones Polifemo, 1998, p. 269.

46 Ibid, p. 72.

47 Ibid., p. 316.

${ }^{48}$ Al respecto es muy sugerente el ensayo de ROUBAUD, Sylvia, "Los libros de caballerías", en la edición de Don Quijote de la Mancha dirigida por F. Rico, Barcelona, Crítica-Instituto Cervantes, 1998, pp. CV-CXXVIII.

49 AZPILCUETA, Martín de. Compendio del manual de confesores y penitentes del Doctor Don Martín de Azpilcueta Navarro.... Valladolid: Diego Fernández de Córdoba, 1586, p. 36. 
logrado a lo largo de los siglos. En 1611, Sebastián de Covarrubias (1539-1613), en su Tesoro lexicográfico, define la voz novedad como cosa nueva y no acostumbrada que suele ser peligrosa por traer consigo mudanza de uso antiguo ${ }^{50}$. El desprecio y la marginación de la prosa novelística, en definitiva, es un topos visible en una importante sección de los intelectuales del Siglo de Oro, a los que no escaparían aquellos más directamente relacionados con el mundo de los impresos y su orden, ni siquiera Nicolás Antonio, quien muestra un evidente desdén al respecto en su monumental Bibliotheca Hispana Nova.

\section{Edad de Hierro, tiempo de fuego}

Pese a lo visto, los decretos, las acciones de las autoridades y los juicios de los moralistas nunca lograron detener el flujo de la literatura fantástica, fundamentalmente porque el rigor de la vigilancia y la interdicción oficiales se concentró en otro tipo de libros verdaderamente perjudiciales para el rumbo de la política monárquica, cuyas secuelas en nada serían comparables a las de los oníricos Amadises y Esplandianes. Al precio que fuere había que impedir el tránsito del credo protestante, o cualquier escrito en lo más mínimo semejante, de textos supersticiosos y heréticos, de libros hebraicos o de postulados científicos que retasen a la ortodoxia y pusiesen en duda los intereses de la Corona.

La literatura religiosa, en efecto, fue el eje prioritario de la represión ideológica estatal y eclesiástica, de sus censuras y prohibiciones desde la aparición de la imprenta. Felipe II, siguiendo los pasos y consejos de su padre en la última y compleja etapa política que le tocó enfrentar, tomó conciencia del peligro que entrañaba el arraigo y difusión que venían experimentando las doctrinas protestantes y calvinistas. A ello se debe que inaugurara su reinado con la institucionalización de la intolerancia, pues como fuere tenía que evitar la penetración de la herejía en los dominios hispánicos, donde alumbrados, erasmistas, místicos y evangélicos de inspiración luterana representaban una seria amenaza, dadas las semejanzas de muchos de sus postulados con los reformados. ${ }^{51}$ El iluminismo - teología de holgazanes decía el dominico Melchor Cano (1509-1560) -, una aberración del misticismo entonces en aumento, participaba de ideas tan próximas a las del protestantismo como la oración de quietud, la luz interior y una relativa valoración de las obras piadosas, las tres un propicio caldo de cultivo de la heterodoxia. El cierre de fronteras, las hogueras y los expurgos serán bastiones preferentes de la estrategia estatal a la hora de aislar cualquier discurso sospechoso.

Una de las figuras claves al servicio de la causa fue el burócrata Fernando de Valdés (1483-1568), teólogo tradicionalista y arzobispo de Sevilla que ocupó el cargo de Inquisidor General, en 1547, radicalmente decidido a liquidar el más mínimo atisbo de protestantismo, o cualquier ápice ideas semejantes. Con estas miras, en 1551 ordenó la retirada de biblias "notadas de algunos errores", en tanto que en 1554 autorizó la publicación de una censura de determinadas ediciones de la Biblias. En la capital hispalense, la cosmopolita sede económica de la Monarquía Hispánica, y emporio del comercio tipográfico intercontinental, el Santo Oficio no cejó en el hallazgo de libros heréticos, a través del insoportable acoso al que sometió a las librerías, nacionales y extranjeras allí existentes, repletas de impresos importados, el acicate de los inquisidores. La insidia de estas batidas se saldó, en 1562, con la incineración en efigie del impresor Gaspar Zapata; la muerte en la hoguera también fue la mala suerte, en 1557, de Julián

\footnotetext{
${ }^{50}$ COVARRUBIAS, Sebastián de: Tesoro de la lengua castellana o española. Madrid: Castalia, 1997.

51 Acerca de la tolerancia, unas propuestas polémicas pueden ser las de SCHWARTZ, Stuart B.. All Can Be Saved. Religious Tolerance and Salvation in the Iberian Atlantic World. New Haven-Londres: Yale University Press, 2008. En la dirección opuesta KAPLAN, Benjamin J.. Divided by Faith. Religious Conflict and the Practice of Toleration in Early Modern Europe. Cambridge-Londres: Harvard University Press, 2007.
} 
Hernández, acusado de introducir libros calvinistas editados en Ginebra. En 1559 le tocó el turno del fuego, en la sevillana plaza de San Francisco, a Luis de Abrego, escritor de libros de iglesia.

El homólogo de Valdés en América fue el dominico Alonso de Montúfar (1489-1572), designado arzobispo de México en 1554, celoso defensor de la ortodoxia religiosa en las antípodas de Zumárraga y Vasco de Quiroga. En el Primer Concilio Provincial Mexicano (1555), calcando lo que se iba decidiendo en Trento, arreció contra el peligro que comportaba la impresión de libros perjudiciales, por ello ordenó que no se estampase obra alguna sin haber sido examinada en el arzobispado, autoridad que debía otorgar el permiso pertinente. En 1559, año de la publicación del Índice valdesiano, recibió el pase de la Suprema para que "todas las personas que tenían libros los exhibiesen ante Nos, por ver si entre ellos había alguno de los vedados en el catálogo y memoriales que nos fueron enviados". ${ }^{2}$ En dicho catálogo constaban la Doctrina de fray Juan de Zumárraga y la de fray Maturino Gilberti. Montúfar tampoco libró de su tenaz purga al material impreso y la doctrina que se ofrecía a los indios; así, en el Segundo Concilio Provincial de México (1565), celebrado con el fin de llevar a la práctica los decretos tridentinos, prohibió a la población india tener biblias y sermonarios. ${ }^{53}$ El establecimiento de la Inquisición en las Indias, en Lima (1570) y México (1571) -quedando los indios fuera de su jurisdicción-, vino a reforzar la eficacia de la interdicción activada. Baste apuntar que inauguró su andadura ultramarina procesando a impresores, autores y lectores; recogiendo y vetando libros y visitando bibliotecas, librerías y los navíos llegados de la península.

Entretanto en 1554 la corona había decretado que todo escrito con la intención de ser publicado antes debía obtener una licencia de Consejo de Castilla, organismo donde los originales se someterían al examen de un corrector oficial. Allí, de ser aprobada la impresión, también se fijaría el costo de los libros de acuerdo al número de pliegos impresos. Con esta medida, ya delineada por los Reyes Católicos, el estado asume, y centraliza en la corte, la censura previa; que en 1558 se hace extensivo a los libros importados, de ser posible previa a su entrada en el mercado. Esta última pragmática es la que reguló la circulación del libro en los reinos de castellanos a lo largo del Antiguo Régimen. ${ }^{54}$ La fórmula acordada es sancionada atendiendo a razones de utilidad pública, de acciones pasadas y futuras, es decir, poniéndose al servicio del fomento de las ciencias y de las buenas costumbres con el fin de mantener el orden de la comunidad. ${ }^{55} \mathrm{Al}$ mismo tiempo exhibe la singularidad española, que, a diferencia de países vecinos, concede un primer plano a los reyes en la difusión de la doctrina ortodoxa y oficial mediante la concesión de privilegios de impresión y el precio tasado de los libros. En suma, la justificación recaía en la certeza de haber

en estos reynos muchos libros, assí impresos en ellos como traydos de fuera, en latín y en romance y en otras lenguas, en que ay heregías, errores y falsas doctrinas sospechosas y escandalosas y de muchas novedades contra nuestra sancta fe cathólica y religión, y que los hereges procuran con gran astucia por medio de los dichos libros, sembrando con cautela y disimulación en ellos sus errores, derramar e imprimir en los corazones de los súbditos y naturales destos reynos sus heregías y falsas opiniones. ${ }^{56}$

52 En FERNÁNDEZ DEL CASTILLO, Francisco. Libros y libreros en el siglo XVI. México: Fondo de Cultura Económica, 1982 , p. 5. Esta obra consiste en una recopilación de documentos inquisitoriales indispensables para el asunto que estamos tratando.

53 Remito a GRUZINSKI, Serge. La colonización de lo imaginario. Sociedades indígenas y occiden-talización en el México español. México: Fondo de Cultura Económica, 1993; y La guerra de las imágenes. México: Fondo de Cultura Económica, 1994. También mis libros Los mundos del libro, op. cit; Atlantes de papel. Adoctrinamiento, creación y tipografía en la Monarquía Hispánica de los siglos XVI y XVII. Barcelona: Rubeo, 2008; y New World Literacy. Writing and Culture Across the Atlantic, 1500-1700. Lewisburg: Bucknell University Press, 2011.

54 BOUZA, Fernando, Papeles y opinión: políticas de publicación en el Siglo de Oro. Madrid: Consejo Superior de Investigaciones Científicas, 2008; y Dásele licencia y privilegio: Don Quijote y la aprobación de libros en el Siglo de Oro. Madrid: Akal, 2012.

55 Imprescindible GARCÍA MARTíN, Javier. El juzgado de imprentas y la utilidad pública. Cuerpo y alma de una monarquía vicarial. Bilbao: Universidad del País Vasco, 2003.

${ }^{56}$ En REYES GÓMEZ, Fermín de los. op. cit., vol. II. La concesión de licencias de impresión y ventas, y todo el complejo 
Desde entonces, el control del libro en circulación será una competencia plena de la Inquisición. La mediación, en la erradicación de las disidencias ideológicas y en el modelamiento de la opinión pública, de una maquinaria represiva del cariz del Santo Oficio no hace más que volver a poner de relieve la progresiva madurez de la centralización política perseguida por la corona, un factor decisivo del recrudecimiento de la intolerancia $^{57}$. Los inquisidores tenían la obligación de inspeccionar imprentas y librerías, controlar la exportación e importación de impresos en los puertos peninsulares y americanos y, siguiendo los dictámenes de Roma, la de confeccionar los catálogos de libros prohibidos y expurgados, los manuales de su ejercicio censorio. De estos últimos, el prohibitorio de Valdés (1559) y el prohibitorio y el expurgatorio de Quiroga (1583-1584) son las principales guías españolas del Quinientos, atrás precedidas por las listas de libros que el Santo Oficio promulgó en 1540 y 1545, y del Índice de 1551, primer índice español, que completaba el de Lovaina de 1550 con las prohibiciones peninsulares. ${ }^{58}$ Durante el siglo XVII estos repertorios irán renovándose y poniéndose al día con las novedades editoriales reprobadas, como demuestran los de 1612, 1632 y $1640 . .^{59}$ A su en 1557 el papa Pablo IV (1476-1559) inaugura los índices romanos modernos, que se aumentará al cabo de dos años y en lo sucesivo, resultando el de 1564, el denominado catálogo de Trento, o el impreso en Venecia en $1644 .{ }^{60}$ En resumidas cuentas, la Inquisición dejó claro que leer, o simplemente poseer, un libro prohibido era un delito equiparable al del autor del libro en cuestión ${ }^{61}$.

La literatura espiritual, su vía mística, fue la víctima propiciatoria de la insidia inquisitorial de este periodo cronológico. Bajo sospecha desde hacía tiempo, en los años cuarenta y cincuenta sería objeto de una fanática persecución. Con la muerte de Carlos $V$ acabó toda una generación de escritores espirituales, cuyas obras, hasta las fechas, habían circulado sin apenas dificultades. Pero el nuevo rumbo en la política religiosa de los Habsburgo, teñido de absolutismo confesional, trajo consigo unas diferentes directrices palpables en el Índice prohibitorio de Valdés de 1559, inquisidor que sentía una visceral aversión hacia el misticismo de masas y las veleidades erasmistas e iluministas. Esto supuso la prohibición de autores de la talla de Francisco de Evia, Bernabé de Palma, Francisco de Osuna, Juan de Ávila, Francisco de Borja, Juan de Dueñas y Luis de Granada; lo mejor del género. La represión desencadenada y el miedo, a la par, condujo a muchos de ellos al arrepentimiento y, acto seguido, a la corrección de sus tratados (Estella, Granada, Carranza, León, etc.); o sea, a la autocensura sin necesidad de recurrir a la violencia. ${ }^{62}$.

No será hasta la publicación de los Índices de Quiroga (1583-84) cuando la materia espiritual, previa rectificación, sea parcialmente reintegrada. Es más, el de 1583 contiene una exculpación y defensa de las

burocrático en torno a la vigilancia del libro, no sólo fue característico de España. En toda Europa podemos encontrar sistemas similares. Para Inglaterra tenemos el excelente estudio de CLEGG, Cyndia S., Press Censorship in Elizabethan England. Cambridge: Cambridge University Press, 1997.

57 MARTÍNEZ MILLÁN, José, "Aportaciones a la formación del Estado Moderno y a la política española a través de la censura inquisitorial durante el periodo 1480-1559", en J. Pérez Villanueva dir., La Inquisición española. Nueva visión, nuevos horizontes. Madrid: BAC, 1980, pp. 537-578.

${ }^{58}$ Una completa información en PINTO CRESPO, Virgilio Inquisición y control ideológico en la España del siglo XVI. Madrid: Taurus, 1983.

59 BUJANDA, José M. de, Index de I'Inquisition espagnole 1551, 1554, 1559. Québec, 1984.

60 PROSPERI, Adriano. Tribunali della coscienza: inquisitori, confessori, missionari, Turín, Einaudi, 1996; y su L'Inquisizione romana: letture e ricerche. Roma: Edizioni de Storia e Letteratura, 2003.

${ }^{61}$ También García Cárcel, Ricardo y Burgos, Javier, "Los criterios inquisitoriales en la censura de libros en los siglos XVI y XVII", Historia Social, 14, 1992.

62 Sobre estas cuestiones BATAILLON, Marcel, op. cit., pp. 494-608; ANDRÉS, Melquiades. Historia de la mística de la Edad de Oro en España y América. Madrid: BAC, 1994; OROZCO, Emilio. Manierismo y Barroco. Madrid: Cátedra, 1981; SÁNCHEZ LORA, José L., Mujeres, conventos y formas de la religiosidad barroca. Madrid: Fundación Universitaria Española, 1988; y el precioso libro de PÉREZ GARCÍA, Rafael M.. La imprenta y la literatura espiritual castellana en la España del Renacimiento. Gijón: Tres, 2006. 
rectas intenciones de escritores como Juan de Ávila, Francisco de Borja o Luis de Granada, justificando la anterior prohibición de sus libros de una manera muy peculiar:

son libros que falsamente se los han atribuido no siendo suyos; o por hallarse en algunos palabras o sentencias ajenas, que con el mucho descuido de los impresores, o con el demasiado cuidado de los herejes se las han impuesto; o por no convenir que anden en vulgar; o por contener cosas que aunque los tales autores, píos y doctos, las dijeron sencillamente y en el sano y católico sentido que reciben, la malicia destos tiempos las hace ocasionadas para que los enemigos de la fe puedan torcer el propósito de su dañada intención ${ }^{63}$.

El daño, pues del romance, los herejes, la imprenta -oficio proclive a herejías- y de la maldad imperante, es decir, de unos virus transmisores de una infición demoníaca que debilita la razón ${ }^{64}$. Después de la criba la mística terminó cediendo a favor de la ascética, y la oración de quietud a la meditación realista o imaginativa, guiada a través de lo concreto y no en lo abstracto, de la Pasión de Cristo, los dolores de la Virgen y las postrimerías del hombre. La nueva espiritualidad española, de este modo, se apartó de cuanto pudiera mínimamente concordar con el protestantismo, abriendo la senda de la literatura devocional contrarreformista que triunfaría masivamente en el Barroco. Es por ello que los títulos de la segunda mitad del siglo XVI se vuelcan en los ejercicios de virtudes ideales para acrecentar la gracia y caridad, tamizados mediante una técnica discursiva de captación irracional que multiplica e intensifica los elementos sensoriales, plásticos y visuales. El fin no es otro que mover al lector a arrepentimiento, miedo, piedad y obediencia, premisas de la disciplina social que, además, facilitará la sustitución de los populares libros de horas. En definitiva, los nuevos textos pretenden organizar la conducta cotidiana de los fieles y, a la vez, ofrecer un instrumento de suma eficacia para los predicadores. ${ }^{65}$

La supuesta acción perniciosa de la imprenta en asuntos de ortodoxia debemos contemplarla no sólo en el apoyo que prestó a la multiplicación y extensión de los discursos sospechosos, sino también, al desarrollo de las lenguas vernáculas, el medio que heterodoxos e integrados emplearon para hacer valer sus mensajes entre las gentes al margen de la lengua, el latín, propia de los escenarios intelectuales. Una de las mayores amenazas expansivas de la literatura impresa nociva estuvo sin duda en el romance, el verdadero estímulo de lectura o audición para el común de una sociedad cada día más curiosa y deseosa de participar en los problemas del siglo. Tal es uno de los alegatos de Fernando de Valdés en el Índice de 1559, el que alude a "los libros de romance y horas sobredichas se prohíben porque algunos de ellos no conviene que anden en romance, otros porque contienen cosas vanas, curiosas y apócrifas y supersticiosas, y otros porque tienen errores. ${ }^{66}$ Similar es el del autor, probablemente fray Juan de la Peña, del informe de censura al Audi Filia de Juan de Ávila: "yo no daría voto para que se imprimiese libro en romance por donde los simples tomasen ocasión de hazerse jueces en cosas tan dificultosas". 67

La literatura espiritual, el flanco al que preferentemente se dirigió la purga ortodoxa de Valdés, tuvo en el vernáculo un instrumento fundamental, al lado de la tipografía, que desde finales del siglo XV facilitó la expansión de la devotio moderna y de sus premisas más comprometidas entre los laicos y, en consecuencia, la ruptura del monopolio de los eclesiásticos. Los deseos de vulgarización de los artífices de esta sección de la literatura religiosa, a pesar al rigor inquisitorial que eliminó la oración de quietud propia de

\footnotetext{
${ }^{63}$ ANDRÉS, Melquiades. Los místicos de la Edad de Oro en España y América. Antología. Madrid: BAC, 1996, p. 83.

${ }^{64}$ Muy interesante es el libro de GRIFFIN, Clive. Journeymen-Printers. Heresy and the Inquisition in Sixteenth-Century Spain. Oxford: Oxford University Press, 2005.

${ }^{65}$ OROZCO, Emilio, "La literatura religiosa y el Barroco". en Manierismo y Barroco. op. cit., pp. 65-132.

${ }^{66}$ BUJANDA, J.M. de. op. cit., p. 72.

${ }^{67}$ ÁVILA, Juan de. Avisos y reglas cristianas sobre aquel verso de David: Audi filia. Barcelona: 1963, p. 14.
} 
la mística, perdurarían a lo largo de la Contrarreforma, como un móvil recurrente entre muchos escritores ascetas en defensa del beneficio y utilidad de sus textos. De todos es conocida la sutil argumentación sobre la cuestión que Fray Luis de León despliega en su De los nombres de Cristo; mas tampoco desmerecen los alegatos, a favor del romance y de un lenguaje sencillo, de los maestros en auge a partir de la conclusión del Concilio de Trento. Sirva el del agustino Hernando de Zárate, quien disculpa la estilística y retórica de su libro, según él "va no sólo en lengua castellana, mas desnudo de la elegancia y primor que en el mundo suele buscar...Mas quiero ser reprehendido del gramático, que no entendido del pueblo". Esta voluntad de llegar al mayor número posible de personas, la enfatiza cuando concluye que "el lenguaje de los doctores no le entiende el indocto, y el de los indoctos todos lo entienden. ${ }^{\text {"C }}$ Creo que bastan las palabras de Zárate y sobran los comentarios.

El desarrollo de la lectura individual y silenciosa, al igual, predispuso una forma de relación con los libros más libre, y privada e independiente del control de la jerarquía eclesiástica; y no menos peligrosa al favorecer una piedad interior y personal sin otro mediador que el texto entre Dios y en creyente, el principio esencial de la nueva espiritualidad. ${ }^{69}$ Esta técnica lectora la iglesia católica, especialmente tratándose de la Biblia, sólo la estimó aconsejable en personas de cierta preparación intelectual y celo religioso -los clérigos ante todo- y no en la generalidad de los fieles. A estos últimos había que mediatizarles su conocimiento personal de la doctrina para impedir lecturas literales e imaginativas. En parte aquí está el origen del énfasis que Trento puso en el deber pastoral, previa formación en determinadas disciplinas, de los eclesiásticos, y en el hecho de no ser necesario para obtener la perfección cristiana un acceso directo a las Escrituras. No obstante, la Iglesia fomentó la conversión de los creyentes en lectores, de obras devotas y piadosas inocuas, con el fin de difundirles una ideología, y la manera de asumirla, a través del libro; en última instancia, el método pretendía el adoctrinamiento y la disciplina social contrarreformistas ${ }^{70}$.

Además, la lectura en silencio dotaba de una importante fuerza de persuasión a los relatos de ficción, el género que despertaba más fácil y peligrosamente la imaginación de los lectores ${ }^{71}$. Esta manera de privatización, para B. Ife otra de las causas de la suspicacia de los moralistas, condicionó las transformaciones discursivas de la narrativa del Siglo de Oro. La utilización persuasiva que los escritores, como Cervantes y los cultivadores de la picaresca, hicieron de la novela autobiográfica buscaba la legitimación de la ficción frente a la censura, haciendo posible que el lector se identificara con el personaje central y, simultáneamente, se distanciara de él, en unos términos que sólo eran viables mediante la lectura íntima e individual que en las fechas progresaba ${ }^{72}$. Bien hacemos en admitir con J. L. Borges que "el arte de leer en voz baja conduciría a consecuencias maravillosas"; y ver al libro como fin y no como instrumento de un fin. El Libro Absoluto. ${ }^{73}$

La lectura oral y colectiva, la que se deseaba preservar entre los simples - el común de la población-, pese de lo dicho, siguió ejerciendo una función de primer orden en una sociedad mayoritariamente iletrada. Pero la técnica individual no conlleva forzosamente el silencio, pues como la privativa, y contribuyendo a la comprensión del texto en los lectores menos entrenados, puede ser

\footnotetext{
${ }^{68}$ ZÁRATE, Hernando de. Primera parte de los discursos de la paciencia christiana...Madrid: Báez de Castro, 1597. La cita procede del prólogo.

${ }^{69}$ Más en CHARTIER, Roger, "Las prácticas de lo escrito", en ARIÈS, Ph. y DUBY, G. (dirs.). Historia de la vida privada. Madrid: Taurus, 1991, vol. 5, pp. 113-161.

${ }^{70}$ JULIA, Dominique, "Lecturas y Contrarreforma", en Historia de la lectura en el mundo occidental, op. cit., pp. $367-412$.

${ }^{71}$ CHARTIER, Roger, "Lecturas y lectores "populares" desde el Renacimiento hasta la época clásica", en Historia de la lectura en el mundo occidental, op. cit., pp. 413-434.

72 IFE, Barry, op. cit., pp. 11-38.

73 BORGES, Jorge L., "Del culto de los libros", en Otras Inquisiciones. Madrid: Alianza, 1995, pp. 110-115.
} 
vocalizada. Leer en voz alta fue una modalidad que, dada su dimensión social, y para acercar el libro a la población analfabeta, también tuvieron en cuenta los literatos de los siglos XVI y XVII en sus composiciones. ${ }^{74}$ Esta práctica, junto con la creación y consolidación de ideas, originó formas de sociabilidad diversas e interrelaciones entre los individuos, que, a juicio de $\mathrm{N}$. Elias, constituyen el principio básico de la dinámica social. ${ }^{75}$ En definitiva, y citando a $\mathrm{P}$. Bourdieu, "interrogarse sobre las condiciones de posibilidad de la lectura, es interrogarse sobre las condiciones sociales de posibilidad de situaciones en las cuales se lee". ${ }^{76}$

Volviendo a los mecanismos del control del libro, en primer lugar he de precisar que la censura perseguía más a los autores y a los agentes económicos del impreso que a sus obras reprobadas. Bastaba que un libro, aun siendo inocuo, hubiera sido editado, escrito, traducido o vendido por un hereje para que fuese condenado; así ocurrió con determinadas ediciones de tratados científicos y de clásicos greco-latinos, materias que tenían una sólida implantación en las prensas de los países reformados ${ }^{77}$. Esta primacía empresarial de los impresores calvinistas y protestantes obligó a Felipe II a centralizar la edición y venta de los libros religiosos de mayor uso clerical: la liturgia. En 1571 parece que el monarca otorgó a Cristóbal Plantino, prototipógrafo real con taller en Amberes, el monopolio de la impresión de breviarios, diurnos, misales y otros manuales, y, posteriormente, el de la distribución de los mismos a los jerónimos del Escorial. Sin embargo J. Moll sostiene que el Rey Prudente no concedió privilegio alguno a Plantino sobre el Nuevo Rezado, siendo los Junta, empresarios venecianos, quienes recibieron algunas ventajas en este ramo editorial $^{78}$. En cualquier caso, no se dejaría de estrechar la vigilancia de la circulación de los textos litúrgicos, como revelan las visitas inquisitoriales de librerías del reino en $1572 .^{79}$

La censura del Santo Oficio, no obstante, acabó siendo incapaz de atajar el problema de modo efectivo, entre otros motivos porque no dispuso de los medios oportunos para adecuar las prácticas a la norma -algo que excepcionalmente suele suceder- ni de un método eficaz para evaluar el grado de peligrosidad de los escritos sospechosos. Todavía en 1585 se seguía exigiendo a inquisidores y prelados mayor empeño y rigor en la inspección de fronteras y cuando hubieren de comunicar el hallazgo de textos prohibidos. En aquel tiempo nadie albergaba la menor duda de la incompetencia de los inquisidores y de los estragos que estaba causándole el contrabando extranjero y nacional. Los títulos de los índices prohibitorios, incluso los de los heresiarcas, circulaban en España y llegaban con cierta facilidad a Indias. Aquí o allí había gentes predispuestas a su lectura y que anteponían la curiosidad pecaminosa y el placer de leer lo vetado a la severidad de un castigo poco probable. Aunque tampoco debemos olvidar la abultada cantidad de permisos de lectura de libros prohibido que la Inquisición concedía, que también restaban eficacia al sistema represivo; pensemos, a títulos de ejemplo en lo habitual de las copias manuscritas de impresos, o en los préstamos cotidianos.

El contrabando, pues, es otro de los núcleos de la cuestión, en el que adquiere una dimensión espectacular la corrupción que caracterizó a los directamente implicados en las transacciones. Hace tiempo

\footnotetext{
${ }^{74}$ FRENK, Margit. Entre la voz y el silencio. Alcalá de Henares: Instituto Cervantes, 1997.

${ }^{75}$ ELIAS, Norbert. Sociología fundamental. Barcelona: Gedisa, 1995, p. 16.

76 BOURDIEU, Pierre, "Lectura, lectores, letrados, literatura", op. cit., pp. 115-124.

77 Son interesantes las conclusiones de GIL FERNÁNDEZ, Luis. Panorama social del humanismo español (1500-1800). Madrid: Tecnos, 1997; y las de PARDO TOMÁS, José. Ciencia y censura. La Inquisición española y los libros científicos en los siglos XVI y XVII. Madrid: CSIC, 1991.

78 MOLL, Jaime, "Plantino, los Junta y el "Privilegio" del Nuevo Rezado", en Simposio Internacional sobre Cristóbal Plantino. Madrid: 1990, pp. 9-23.

${ }^{79}$ Las actas de dichas visitas han sido publicadas por GARCíA ORO, José y PORTELA SILVA, María J.. Felipe /l y los libreros. Actas de las visitas a las librerías del Reino de Castilla en 1572. Madrid: Cisneros, 1997.
} 
que quedó probada la intervención de ministros inquisitoriales y funcionarios en un sinfín de operaciones ilícitas, sin la cual no se hubiera dado el contrabando ni un incumplimiento tan generalizado de las leyes. Más graves aún fueron las corruptelas de los miembros del Santo Oficio encargados de inspeccionar los navíos en los puertos peninsulares de entrada y salida, quienes, durante la visita, aceptaban dineros, negociaban productos y eran agasajados con una comida por los responsables del barco a cambio de una "distracción" voluntaria. Todo ello hacía muy aconsejable el recurso de las portadas falsas entre las artimañas para introducir literatura prohibida ${ }^{80}$. Los inconvenientes del tráfico comercial despejados tenían una muy compleja solución, debido, antes que nada y desde mediados del Quinientos, a la excesiva dependencia española de la tipografía extranjera, un problema, de sobra conocido por las autoridades, que impedía en gran medida la eficacia de la política de control.

Gobernantes, impresores e intelectuales alzaron la voz pidiendo remedios, o aconsejándolos, con miras a relanzar los tórculos hispanos, aunque ninguna de las propuestas esbozadas llegaría a ser realidad. No obstante, los interesados coincidían a la hora de contemplar medidas mercantilistas como la vía capaz de reparar los daños causados, o lo que es lo mismo, de potenciar y proteger la industria nacional frente a la foránea y, a la vez, reducir las importaciones. Como fuere, y sin echar en olvido las secuelas de la revolución de los precios, la política exterior de los Austrias, en lo sucesivo, complicaría aún más la situación e impediría acometer las reformas oportunas.

Ahora bien, una buena parte de la población de la Alta Modernidad, incluidos muchos clérigos rurales, por carecer de la información necesaria, de medios económicos y de alternativas tipográficas, desconocía los pormenores de la ley y continuaba manejando ediciones de breviarios, calendarios, horas, devocionarios, misales y otros impresos censurados de los que no percibían daño alguno. Esta peculiaridad del sistema estuvo presente en la casuística de la teología moral, disciplina que en dichas situaciones suele pronunciar un dictamen como el de Francisco Ortiz Lucio: "Los que probablemente ignoran la prohibición de un libro, no pecan, ni incurren en las penas de excomunión si le leen y tienen, pero si lo saben sí". ${ }^{81} \mathrm{La}$ interdicción, un tipo de fiscalización cotidiana en la época y en toda Europa, obviamente, no logró coartar la fuerza expansiva de las ideas. Si el poder las reprueba, porque las considera una amenaza, siempre encuentran cauces paralelos en los que tomar forma y discurrir hacia vías espirituales y materiales. Pero la norma, sin ser el medio ideal para llegar hasta la meta represiva deseada por el poder, el control de la imaginación, al menos generó desconfianza hacia la lectura y disminuyó, todavía más, las precarias inquietudes culturales de entonces. ${ }^{82}$ Al final se impuso la pedagogía del miedo, al castigo y al pecado que conllevaban determinados autores y escritos.

Los libros "dañinos", de acuerdo a la concepción organicista de la realidad vigente en el siglo XVI, eran equiparados a un germen infeccioso, idéntico a los que provocaban las enfermedades epidémicas; y sus lectores a unos enfermos necesitados de la cura del médico gobernante. Por ello quien censura la lectura es el que mejor cree en sus efectos contagiosos. Así, los libelos producen desobediencia civil y rebeldía; los textos de herejes, la perversión de la fe; y la literatura fantástica, el deterioro de las virtudes cristianas. De la causa surge el remedio: la seducción maléfica de los libros infectados se combate con libros sanos; de ahí que, siguiendo con la receta, la ficción caballeresca la cauterizaron con la épica, las vidas de santos y el género didáctico-moral; la oración de quietud, con la imaginación realista; el

\footnotetext{
${ }^{80}$ VÉASE FERNÁNDEZ DEL CASTILLO, Francisco, op. cit., pp. 351-400.

${ }^{81}$ ORTIZ LUCIO, Francisco, Summa..., op. cit., p. 225.

82 VÉASE WHINNOM, Keith, "The Problem of the "Best-Seller" in Spanish Golden-Age Literature", Bulletin Hispanic Studies, LVII, 1980, pp. 189-198.
} 
maquiavelismo, con el neoestoicismo; y el humanismo cristiano, con la neoescolástica. A cuento vienen las reflexiones de espirituales y moralistas; la del agustino Pedro de Valderrama, quien estima que "los libros que tratan cosas espirituales, y medicinar las almas, médicos son, y pues los que los compran tienen alguna enfermedad de que pueden curarse con su doctrina. ${ }^{83} \mathrm{Y}$, considerando la terapéutica oportuna, Fray Luis de Granada:

\begin{abstract}
Veemos que uno de los grandes artificios que han tenido los hereges de nuestros tiempos para pervertir los hombres, ha sido derramar por todas partes libros de sus blasphemias. Pues si tanta parte es la mentira pintada con los colores de las palabras para engañar: quanto más lo será la verdad bien explicada y declarada con sana doctrina para aprovechar. ${ }^{84}$
\end{abstract}

Antes de finalizar sería aconsejable intentar responder acerca de las repercusiones que la censura inquisitorial y la legislación de los Austrias Mayores tuvo en los sectores editoriales y comerciales de la monarquía hispánica. Las respuestas de solvencia son divergentes y para todos los ánimos, optimistas y pesimistas. Si L. Gil le atribuye la esclerosis de nuestro comercio e industria editorial de los siglos XVI y XVII, sobre todo del libro culto, y de las dificultades de la dinámica intelectual, J. Moll, por acudir a la opinión de dos reconocidos expertos, no observa ninguna consecuencia de acusado relieve. Para este último los editores españoles disponían de un gran número de obras de difusión internacional, al margen de la censura, que hubiesen obtenido la licencia de impresión sin ningún contratiempo. Su conclusión la argumenta en la libre circulación de una ingente cantidad de libros publicados en España, y en el extranjero, frente al exiguo volumen de los libros prohibidos ${ }^{85}$. La diversidad y el número de los impresos, en español y latín, de edición nacional y extranjera que podemos apreciar en la época, frente a los 550 autores, con todas sus obras, vetados en el índice romano de 1557, las 670 prohibiciones del Índice de Valdés, o los 12 autores procesados a lo largo de todo el siglo, apoya la tesis de J. Moll; pero no menos palpables son las actitudes conformista y convencionales, las autolimitaciones, el temor, las dudas y la ausencia de espíritu crítico que la censura originó en la creación intelectual y literaria. Al conocimiento se le privó de unas ideas del exterior imprescindibles para su avance y desarrollo; pensemos, entre otros episodios, en la condena de las proposiciones de la astronomía renacentista y de la revolución científica del siglo XVII, que, aceptadas en España en fechas muy tardías, provocarán un considerable retraso de nuestra ciencia ${ }^{86}$.

Mas la censura siempre supone la ruina de negocios editoriales, oculta ediciones y supone un claro riesgo para los escritores, o lo que es lo mismo, origina el clima de miedos, recelos, suspicacias y denuncias que provocó la presencia de la Inquisición. Su balance no puede ser más desolador: entre los años 1559 y

${ }^{83}$ VALDERRAMA, Pedro de, Exercicios espirituales para todos los días de la Quaresma, Sevilla, Francisco Pérez, 1602, vol. I, p. 12.

${ }^{84}$ GRANADA, Luis de. Introductión al symbolo de la fe. Salamanca, 1585, p. 520.

${ }^{85}$ GIL, Luis. Panorama social del humanismo español (1500-1800). Madrid: Tecnos, 1997, p. 538. MOLL, Jaime. "EI impresor y el librero en el Siglo de Oro", en ASÍN, F. (dir.), Mundo del libro antiguo. Madrid: Complutense, 1996, pp. 27-41; y GARCÍA CÁRCEL, Ricardo, Las Culturas del Siglo de Oro. Madrid: Historia 16, 1999, pp. 170-180; del mismo autor junto con Doris Moreno, Inquisición. Historia y crítica, Madrid: Temas de Hoy, 2000. Más recientes son el libro de ALCALÁ, Ángel. Literatura y ciencia ante la Inquisición española. Madrid: Laberinto, 2001; y el de MORENO, Doris. La invención de la Inquisición. Madrid: Marcial Pons, 2004.

${ }^{86}$ Más sobre la censura en PEÑA DíAZ, Manuel. "La censure inquisitoriale en Espagne aux XVle et XVIle siècles", La Lettre Clandestine, 9, 2000, pp. 143-155; y "Leer con cautela: estrategias y nuevos modos de censurar en el siglo XVII", en Historia y perspectivas de investigación, Mérida, Editorial Regional Extremeña, 2002, pp. 365-370. GUIBOVICH PÉREZ, Pedro, Censura, libros e Inquisición en el Perú colonial, 1570-1754. Sevilla: Universidad de Sevilla, 2003; Ramos, José A., "El "santo oficio" de los calificadores de libros en la Nueva España del siglo XVIII", en C. Castañeda coord., Del autor al lector, México: CIESAS-Porrúa, 2002, pp. 179-200; y VILLALTA, Luiz C., "Censura e "romances": notas sobre as proibiçôes, a circulaçâo e a posse dos livros de prosa de ficçâo na América Portuguesa (1768-1821", en ABREU, M. y SCHAPOCHNIK, N.(eds.). Cultura letrada no Brasil: objetos e práticas, Campinas: Mercado de Letras, 2005, pp. 161-182. 
1707, 461 autores prohibidos y 759 obras científicas incluidas en los Índices (204 de ellas confiscadas) y más de 3000 títulos secuestrados, la mayor parte de los cuales ni siquiera figuraban en los Índices. No falta, por tanto, razón a Bethencourt cuando argumenta que la cuestión no reside en saber cuántos libros prohibidos superaron las barreras inquisitoriales, cuántos se conservaron o cuántas personas los leyeron; el problema es que tales libros no eran productivos, no se podían incorporar a las conversaciones cotidianas, no podían servir como referencia expresa y no podían tener un papel efectivo en los movimientos de opinión de las elites letradas ${ }^{87}$. Terminaré con Borges diciendo, como él, que un libro, cualquier libro, es para nosotros un objeto sagrado ${ }^{88}$.

Carlos Alberto González Sánchez: Doutor em História e Professor Catedrático de História Moderna da Universidade de Sevilha. Suas pesquisas voltam-se para a história do mundo Atlântico ao longo dos séculos XVI e XVII e para os estudos da cultura escrita e da censura na América ibero-americana. Autor de vários livros, entre os quais, Testigo del tiempo, memoria del universo. Cultura escrita y sociedad en el mundo ibérico (Barcelona 2009).

\footnotetext{
${ }^{87}$ BETHENCOURT, Francisco, La Inquisición en la época moderna. España, Portugal e Italia, siglos XV-XIX. Madrid: Akal, 1997, p. 263-265.

${ }^{88}$ BORGES, Jorge L.: "Del culto de los libros". op. cit.
} 